\title{
Political Science in Central European Democracies Under Pressure
}

\author{
Aneta Világi, Darina Malová, and Dobrinka Kostova
}

\section{INTRODUCTION}

In most parts of Central and Eastern Europe (CEE), in recent decades political scientists have faced similar tasks and challenges in establishing political science (PS) as an academic discipline. Firstly, for many of them it was necessary to distance themselves from the communist legacy; secondly, they had to adapt to international (Western style) academic standards; and thirdly, they sought to gain academic independence and public recognition. The development of political science in these various countries has been characterised by national specificities as well. This is why comparing them is a useful approach that could bring fruitful

\footnotetext{
A. Világi $(\bowtie) \bullet$ D. Malová

Department of Political Science, Faculty of Arts, Comenius University in Bratislava, Bratislava, Slovakia

e-mail: aneta.vilagi@uniba.sk; darina.malova@uniba.sk

D. Kostova

Department of Public Policies and Social Changes, Bulgarian Academy of Sciences, Sofia, Bulgaria

(C) The Author(s) 2022

G. Ilonszki, C. Roux (eds.), Opportunities and Challenges for New and Peripheral Political Science Communities, https://doi.org/10.1007/978-3-030-79054-7_5
} 
cross-national insights into national patterns. This chapter examines the challenges six CEE democracies (Bulgaria, the Czech Republic, Hungary, Poland, Romania and Slovakia) have faced in the development of political science over the last three decades. It also aims to contribute to a better understanding of the theoretical frame and the institutionalisation of political science as an academic discipline in Europe. In particular, we shall explore the institutionalisation of the discipline by focusing on its two principal characteristics: stability and legitimacy.

In this chapter, we show that political science as a new social science in the CEE region has acquired a relatively stable position. The discipline has gained autonomy and managed to form its own identity, and has shown a capacity to cope with several challenges that have arisen. However, some of the structural reforms, including the commodification of higher education ( $\mathrm{HE}$ ) and the proliferation of political science at universities and other teaching institutions, have recently undermined the stability it had previously gained, as it progressively suffers from a loss of public recognition. We argue that the oversimplified, technocratic approaches of governments in recent years have impaired the legitimacy of the social sciences, and of political science in particular. This common trend is observable in all of the selected countries, albeit with certain variations from one country to another.

Over the last decade, the whole CEE region has experienced a degree of democratic backsliding, and even countries once perceived as 'consolidated democracies', such as the Czech Republic, Hungary, Poland and (after 1998) Slovakia, have shifted towards becoming 'defective democracies' (a classification primarily attributed to the political regimes in Bulgaria and Romania, even after their accession to the European Union (EU)) (Eisfeld \& Pal, 2010). We have also observed an interesting development regarding the debate on political science as an academic discipline. In a situation of increasing democratic backsliding, certain serious attempts to lessen its legitimacy have been made, mainly by populist governments. We believe that political science as a 'vested discipline' concerned with democratic principles might be perceived as an obstacle to a democratic U-turn in those countries. The weakened legitimacy of the discipline might subsequently influence the overall institutionalisation of political science, as it could undermine its stability, understood as two possible, basic types of stability as defined by Sven Ove Hansson and Gert Helgesson's (2003). Their analysis shows that there are two basic types of stability: the first 
concerns constancy (the actual absence of change), while the second regards resilience (the ability of a system to cope with perturbation).

First, we introduce the historical context that shaped the institutionalisation of political science in CEE before, and shortly after, the collapse of the communist regimes. In this regard, we consider the selected countries' transition to democracy as a decisive starting point. We recognise that there were differences among the previous regimes (particularly in view of the 'controlled liberalization' ${ }^{1}$ witnessed in Poland and Hungary). Yet the very essence of communist rule did not permit political science to achieve full autonomy in any of the countries under Soviet tutelage. Therefore, we treat all of the countries in the same way, and we take as our starting point the collapse of the previous regime. We then look at the current state of the discipline, and particularly at two of the key proprieties of institutionalisation: stability and legitimacy. We consider these two properties as the most relevant in regard to the recent phase of institutionalisation over the last decade in CEE. This focus reflects the de-legitimisation efforts of the political elite and the industrialist lobbies, targeting social science teaching programmes, in particular those concerning political science. Our approach touches on the public debate concerning the relevance of political science and thus connects to Chap. 7 in this volume to some degree. We look for the indicators of stability in the number of institutions providing higher education in political science, their durability in terms of the number of students enrolled in the discipline and the structural changes affecting political science. As the overall trends indicate a worsening of political science performance, as shown by the declining number of students, we look at specific cases to reveal the ways in which governments interfere in public discourse and set up institutional arrangements designed to lessen the legitimacy of social sciences, and of political science in particular. Finally, we argue that the institutional stability of individual organisations (the political science profession, departments, research institutes and associations) had been established by the end of the 1990s; however, the proliferation of teaching units since the turn of the new millennium, where the sole focus was on profit rather than on educational and professional goals, has undermined the overall quality of the discipline and has challenged its hard-earned public recognition. The chapter is based mainly on expert assessments (PROSEPS National Reports on the State of the Discipline) and

\footnotetext{
${ }^{1}$ For more detailed argument, see Gebethner and Markowski (2002) and Arató and Tóth (2010).
} 
quantitative empirical data gathered within the context of the COST Action CA 15207 PROSEPS-Professionalization and Social Impact of European Political Science.

\section{The Context of the Institutionalisation of Political SCIEnce in CEE}

The history of political science in CEE is a complicated one. In the early years of the twentieth century, the unspecified field of political science was dominated by political philosophy (normative political theory) and 'old' institutionalism (formal-legal analysis). Then shortly after World War II, when Stalinist orthodoxy and Marxist ideology took over all aspects of political life in the CEE, academic life followed the same path, leaving no room for any independent study of politics. Departments of (scientific) Marxism-Leninism swiftly replaced the political science chairs ${ }^{2}$ that had been established in the early post-war period (1944-1948), and the party's regular congresses defined the theoretical and methodological approaches to be followed by the social sciences. Partially deviant cases of the penetration of communist ideology into political science were those of Poland (from the 1960s) and Hungary (from the 1980s). Political science in these two countries witnessed a kind of controlled liberalisation, involving the abolition of mandatory courses in Marxism-Leninism, and a regulated openness to international influences (e.g. access to Western literature in the field, participation at the IPSA World Congress in 1979). Though the short-lived Prague Spring of 1968 introduced similar changes in the former Czechoslovakia, the new non-Marxist study programs including political science quickly vanished soon after the country's occupation that same year.

It was only after the collapse of the regime in the early 1990s that political science gained impetus as a new academic discipline focusing on new phenomena such as the democratic political order. Some scholars have perceived political science as a vested discipline immersed in democratic ideals, projected towards the promotion of democracy (Ágh, 1991; Huntington, 1988). Political science in CEE also inherently aims to help

\footnotetext{
${ }^{2}$ As previously stated, political science chairs in some countries like Poland or Romania dates back even further, to the inter-war period. In the former Czechoslovakia, an independent School of Political and Social Sciences was founded in October 1945 (Holzer \& Pšeja, 2010). In Hungary, political science chairs were first established in 1944 (Ágh, 1991).
} 
mould active citizens committed to support for democracy. It is supposed 'to help citizens prepare themselves for various possible futures' (Hankiss, 2002 , p. 22). Otherwise, 'perplexity, distrust, fear and intolerance' may overwhelm large segments of society (ibid., p. 20), making them strike out against democratic principles and practices. Thus, the development of political science in these countries was closely connected to the democratic developments seen in the region over the last 30 years. Political science has aimed to explain how historical experiences, memories and political cultures shape the political debate, and their implications in terms of the degree of consensus/dissent with regard to the future of democracy in each country and its European integration, among citizens and political elites, as well as between them. In other words, at the early stage of the process of democratic transformation, the challenge for political science was to reinvent politics in order to cope with the new system of governance, which was characterised by an extraordinary discrepancy between the socialist past and the challenge of democratic development. Political science was expected to have the capacity to scientifically explain the democratisation process, and to serve educational purposes at the same time. From the very beginning political science was tasked with a dual role: (a) to build the capacity to scientifically explain the democratisation process; and (b) to serve educational purposes.

This twofold role was self-imposed by political scientists themselves, and also something that the public expected of it to a certain degree. Nowadays, however, because it deals with politics, political research-or rather the way it is portrayed in the mainstream media-is often criticised by politicians, and therefore some of them perceive the very existence of the discipline as a challenge. Since the early 1990s, the educational and scientific community is longer indifferent to public scrutiny. And it is this increased relevance of opinion which constitutes the structural background for the growing importance of both the previously unknown diversity of ideas, and the reaction to three decades of changes, that have marked the development of political science. That is why, compared to other social sciences, the impact of political science in the CEE countries examined here has been considerable over the last 30 years, due to the need to explain and promote the democratisation of society. Political scientists have been regularly adopting public stances in the media and participating at seminars and conferences targeting the broader public 
(informal civic education). Political science students and graduates have even been participating directly in politics. ${ }^{3}$

In this context, the first characteristic feature of political science in the CEE region has been its focus on the management of the new political regime (Eisfeld \& Pal, 2010). In return, the role of political science and political scientists in the promotion of new democratic principles has contributed towards recognition of its purpose and justification and has furthered general acceptance of the discipline and its legitimacy. At the same time, the establishment of new political systems has influenced the profiling of the discipline to some extent. Political science has focused on explaining the day-to-day functioning of the new system and new political institutions. The emphasis has been on current politics and policy-making (offering expertise, monitoring and normative comparison with Western standards), rather than on any fundamental theoretical contribution (Arató \& Tóth, 2010; Barbu, 2002; Gebethner \& Markowski, 2002; Rybár̆, 2010; Szabó, 2002).

The second specific feature of the newly established political science has been the common perception of democratisation in terms of the acceptance of Western political values and standards. It has considerably influenced the development of the discipline (Kostova \& Avramov, 2010). The transfer of knowledge and methodological standards has been conducted through cooperation networks of scientists and, more importantly, through the translation of seminal works ${ }^{4}$ which have influenced education and research in the field.

However, despite these efforts, political science in the CEE region is far from being on an equal footing with its Western equivalents. Structural and personnel difficulties have significantly hindered the development of political science in Central Eastern European countries. Immediately after

\footnotetext{
${ }^{3}$ Some examples of this are as follows: Hungarian Prime Minister Viktor Orbán, who briefly studied political science at Pembroke College, Oxford in 1990; Iveta Radičová, Slovak Prime Minister (2010-2012), was a professor at Comenius University in Bratislava and Slovak Minister of Defence (2006) Martin Fedor graduated from this department, too; Dana Prudíková, State Secretary at the Czech Ministry of Education, Youth and Sports (since 2015), graduated in political science from Masarykova University in Brno; Mariya Gabriel, Bulgarian EU commissioner, graduated from the Institut d'Etudes Politiques de Bordeaux; and so on.

${ }^{4}$ For example: The Theory of Democracy Revisited by Giovanni Sartori; A Theory of Justice by John Rawls; Democracy and Its Critics by Robert Dahl; Sociology of Politics by M. Duverger or Totalitarianism by Hannah Arendt.
} 
the fall of Communism, the main constraints on the professionalisation process (in addition to funding issues) concerned the low degree of knowledge transfer mainly resulting from a lack of active foreign (namely English) language skills, which hindered the full internationalisation of teaching and research. In the mid-1990s this situation changed thanks to special scholarships, the opening of borders and the close contacts that followed, which together resulted in an improvement in the professional and linguistic knowledge of political scientists in the CEE countries. It fuelled international cooperation focusing on research topics suggested, as well as funded, by Western scholars and institutions. It led to an improvement in political science curricula. ${ }^{5}$ A further positive factor was the availability of visiting scholarships available at Western universities (in EU member states and the USA), sponsored by foreign governments (e.g. the Fulbright Program) and/or private foundations (e.g. Andrew W. Mellon Foundation, Open Society Institute) or EU programmes (e.g. TEMPUS). Although there are nowadays a number of well-developed political science programmes at all levels of higher education in CEE, the scientific expertise, methodological training, research infrastructures and financial conditions are not sufficient to 'catch up' with Western academia and to prepare competitive research projects within the European Research Area. This is analysed in detail in Chap. 8.

\section{The Stability of Political Science in CEE: Virtually No Change or Weak Resilience?}

Institutionalisation is perceived as a process by which certain properties or outcomes are obtained. As Gabriella Ilonszki points out in her chapter in this book, the stability of the profession is a key property of institutionalisation. Therefore, we first focus on this attribute of institutionalisation. The vast literature on the institutionalisation of politics and political organisations (for a review, see Ilonszki in this volume) tells us, however, that the evolution of - the very path towards - the stabilisation of any

\footnotetext{
${ }^{5}$ For example, the Department of Political Science at the Faculty of Arts, Comenius University in Bratislava (Slovakia), has participated in several projects targeting an improvement in political science curricula. It has worked with the University in Manchester on the introduction of human rights and regional comparative studies; with the University of Groningen on the introduction of security studies; and with Leipzig University on the incorporation of political symbolism into PS curricula.
} 
organisation or phenomenon, including professions and academic disciplines, cannot be taken for granted. In this regard, individual countries, regions and time periods differ substantially in terms of the degree of stability of political science's development as a discipline and profession, although some common, albeit rather general, traits are observable.

Firstly, political science was established as one of the outcomes of democratisation. Only in a democracy is it possible to have autonomous, independent social sciences free of the influence of government and/or party ideology.

Secondly, from the point of view of the institutionalisation of political science in the CEE states, the discipline seems to be impacted by a series of countervailing factors. The region's proximity to Western Europe, its relatively high level of education, these nations' membership of the European Union, and the demand for experts in politics and democratic procedures, are all assumed to foster political science institutionalisation. However, the legacies of Communism, overall economic volatility, a lack of financial and organisational resources for education, and the shortage of well-trained professionals (political science teachers) are likely to hinder the very same processes.

Thirdly, we are currently faced with a peculiar sequence of political science developments requiring a certain caution concerning stabilisation. While by the end of the 1990s, some of the properties of institutionalised political science, such as the persistence of individual departments, and the identity and autonomy granted by the new, or renewed, national associations were already in place in CEE, and as such contributed to the discipline's stability, their reproduction and legitimacy linked with the discipline's resiliency, have not been fully tested yet.

Finally, we argue that the legal and structural changes seen in higher education after the turn of the millennium, and initiated by EU membership, have in fact undermined the emerging internal stability of political science, and have gradually hindered reproduction and led to the questioning of political science's legitimacy by those outside the discipline, that is, by certain politicians. The main driver behind this trend has been an over-simplistic understanding of labour market needs, and, somewhat paradoxically, the efforts made to introduce transparent financing of public higher education and research.

In these conditions, measuring stability is not a simple task, since stability in terms of the discipline's endurance is a dynamic, rather than static, variable. Therefore, we need data for the indicators of stability, such as the 
number of political science chairs in a given country, the number of political science programmes available, and the discipline's professional organisation; and we need to interpret them in terms of their rise or fall; however, this is only one part of the problem. Another matter is the need to analyse the very process of institutionalisation, which we understand as resilience, i.e. the capacity of the discipline to face up, and adapt, to its challenges engendered by changing structural factors, such as governmental policies, socio-economic development and demographic trends (Hansson \& Helgesson, 2003). In the next section, we shall focus on the indicators of stability, namely on those institutions where political science is taught, and student numbers, within the context of structural reforms and demographic trends, and their impact on the durability of the discipline in the area.

\subsection{Higher Educational Institutions in the Field of Political Science: A Review of Institutional Trends Over Time}

In CEE the system of higher education (HE) has been shaped by various structural reforms since the early 1990s. Despite the fact that such reforms differ somewhat from one country to the next, it is possible to draw certain similarities among the 'V4' countries (Poland, Hungary, the Czech Republic and Slovakia), Bulgaria and Romania. Crucial reforms have impacted the financing of $\mathrm{HE}$ institutions and accreditation processes and have subsequently impacted political science as a discipline. Major structural reforms of higher education in the selected countries can be examined in line with the institutionalisation processes analysed by Di Maggio and Powell (1983). For these authors, the institutionalisation impetus, and the source of legitimacy, for change, come about in three ways: they can be coercive, that is, imposed by external actors (frequently a state or an international organisation); they can be normative, when the driving force for change is to settle certain norms and rules that diverge from those previously used (usually from within the institution), and they can be mimetic when the level of uncertainty is high, and institutions tend to mirror the path taken by other institutions (mainly when the practices concerned are seen as useful and advantageous). ${ }^{6}$ We argue that our sample of countries is characterised by three phases of institutionalisation, all of which took place in a mixed manner: the first, the emancipation phase,

${ }^{6}$ For more details, see also Chap. 2 of this book. 
occurred in a mimetic, partly normative way; this was followed by the proliferation phase; and then the third, regulatory phase occurred, with both second and third phases being initiated by government policies. While the proliferation phase led to an enormous increase in the number of political science departments, study programmes and students, the regulatory phase has led to a fall in student numbers and the de-legitimisation of the discipline. The latter two periods can be defined as predominantly coercive, with mimetic imprints in the case of the proliferative phase, and normative factors characterising the third phase.

During the first period, which was shortly after the fall of Communism (early 1990s), changes affecting education, including political science in higher education, were implemented within the framework of a complex transformation of society. The development of political science in the CEE region had entered an introductory, emancipation phase of the process. Many universities transformed their social sciences programmes at that time. Thus standard 'Western' programmes were introduced, including political science as a new discipline in most cases. Political science was (re) established usually within the official education system. The main pattern consisted in a reform of the existing units (in most cases labelled 'Departments of Scientific Socialism/Communism'), as the cases of Hungary, Poland, Slovakia, Romania and Bulgaria, or in the establishment of new units, as happened in the Czech Republic. Universities used personnel from disciplines less tainted by scientific socialism, such as sociology, philosophy, history or law, ${ }^{7}$ and/or émigrés and external experts, mainly arriving from the United States and the EU under the TEMPUS programme.

A rather specific path for the launching of political science was followed by Poland, and to a degree also by Hungary and Bulgaria. In these three cases, institutions providing education in political science were established prior to 1989. In Poland, compulsory courses in political science were introduced in the mid-1960s for all students at all universities. Consequently, political science was acknowledged as a separate academic discipline, and as early as 1964 (at the University of Poznan) political

\footnotetext{
${ }^{7}$ This is clearly evident from the professional background of the 'founders' of the discipline in each country, namely: Prof. Semov-sociology (BG); Prof. Kučera-philosophy and history (CZ); Prof. Bihari-law and sociology and Prof. Ágh-philosophy (HU); Prof. Danecki-sociology (PL); Prof. Barbu—history and philosophy (RO); Prof. Kusý-philosophy (SVK).
} 
science departments were created offering full four-year curricula. Similarly, in Hungary the first chair in political science was created in the 1980s at the 'Department of Political Theory' at Corvinus University, Budapest, while the Bulgarian 'Department of History and Theory of Politics' at Sofia University was established in 1986. However, it is important to note that academic staff were recruited from among lecturers of Marxism-Leninism, and partly served the Communist Party's goals (PROSEPS National Reports, 2019a, c, d). As the Communist regime did not allow the discipline to develop as an independent entity, we shall treat all countries in the same way, and take as our starting point the collapse of the previous regime.

The early 1990s marked a new beginning for political science in all of the countries concerned. According to the PROSEPS National Reports, within five years of the collapse of Communism, at least three public universities were providing an academic programme in political science in each of those countries. ${ }^{8}$ Symptomatic of this period of political science institutionalisation was the rather prompt transformation of previously existing Departments of Marxism-Leninism, into departments of political science and/or politology. Due to the lack of any regulatory framework that could have set out strict rules for the accreditation process shortly after the collapse of the communist regime, HE intuitions followed the clever pattern of renaming previously existing departments. In most cases, the core staff in such departments remained the same. In the words of $\mathrm{Di}$ Maggio and Powell, this should be considered a normative period in the case of the leading institutions (those instituting their first chairs in political science), as the main goal was to introduce academic programs in line with Western professional standards and goals (PROSEPS National reports, 2019a-f). We would argue, however, that at the same time, mimetic methods were adopted whereby other faculties, including the newly established ones, mirrored the steps of the leading universities. However, as a consequence of further regulation and increased competition, many of such departments which were politological 'only by name', subsequently disappeared. On the other hand, almost all leading national institutions with a chair in political science (with the exception of Romania) have proved their credentials, and continue exist to the present day (for the list, see Table 5.1).

\footnotetext{
${ }^{8}$ See also Eisfeld and Pal (2010) or Kaase et al. (2002).
} 


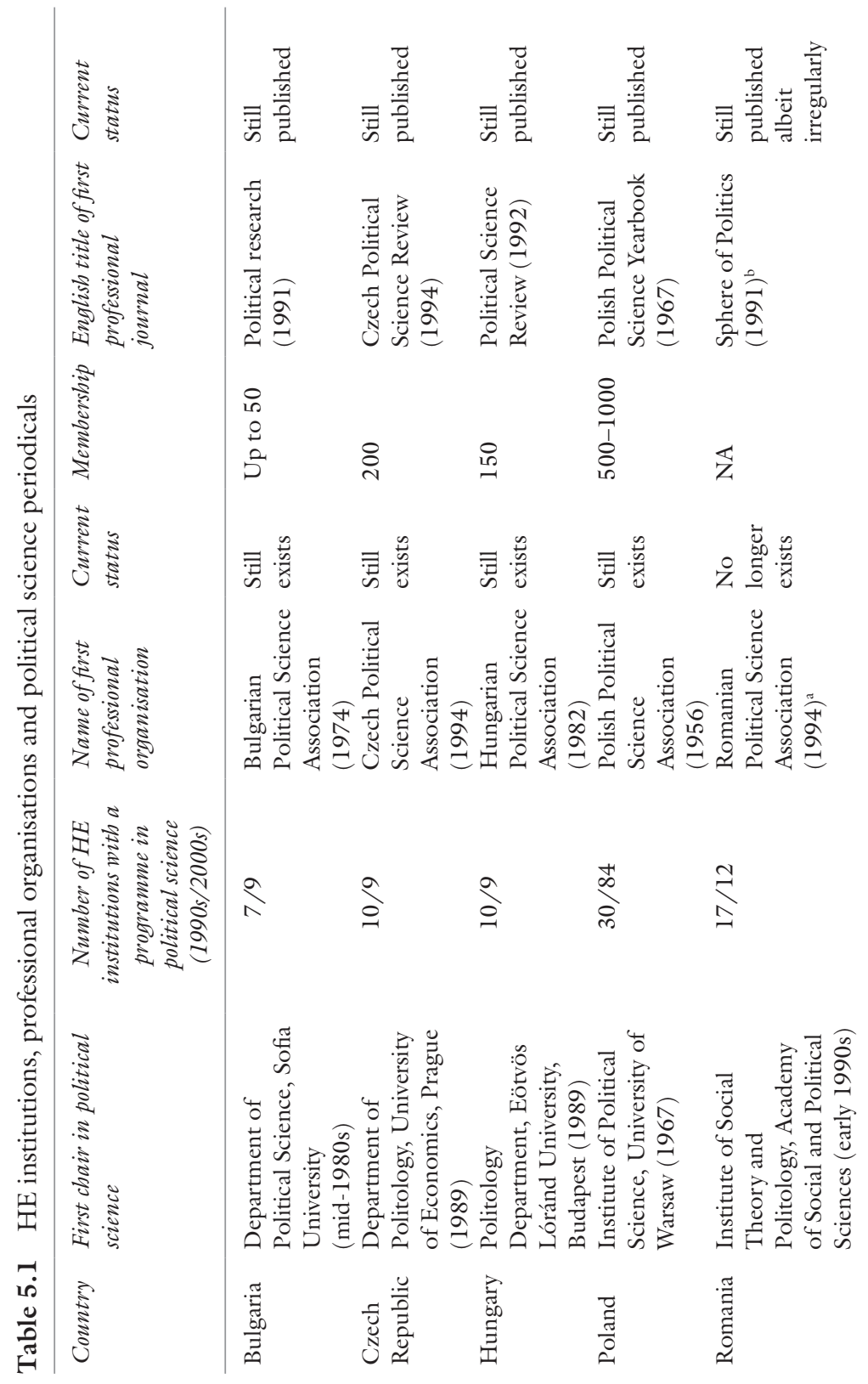




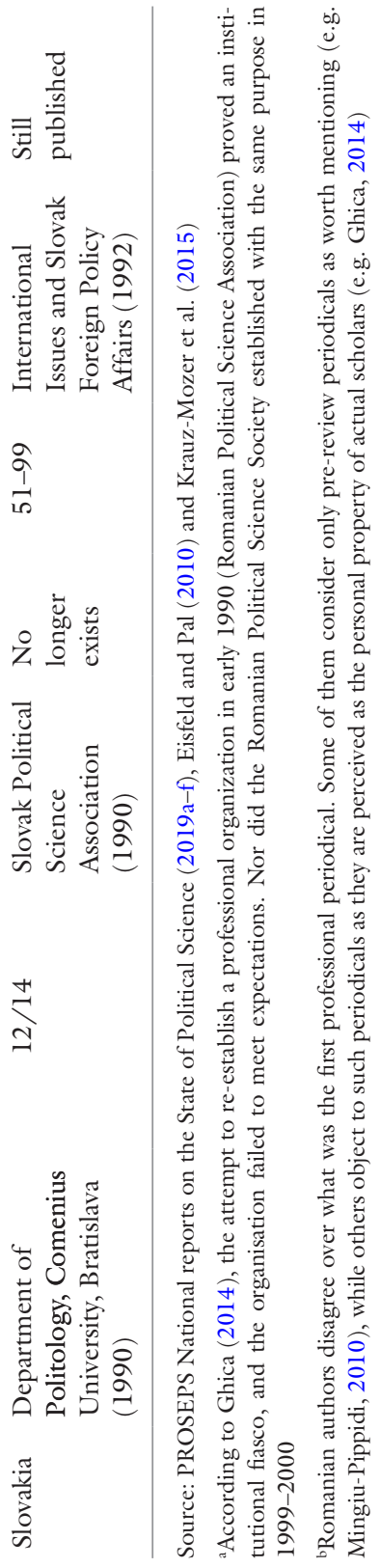


During this phase, other institutions were established which were also important for the development of the discipline, namely the professional organisations representing political scientists in the country, and the professional journals concerned with political science. While political science journals managed to prove their durability (with publication still ongoing), the history of the professional organisations has been rather more unpredictable. In some cases, such as Bulgaria, Poland and Hungary, these organisations are well-established and have been active for almost forty years. In others, especially those of Romania and Slovakia, the professional organisations were only active for a limited period, slipping into a period of 'hibernation' shortly after being established. Nevertheless, at that specific time (the early 1990s), the emergence of these organisations helped political science gain recognition as an autonomous, fully fledged discipline.

The second phase of development of political science could be labelled as the proliferation phase, and was seen from the late 1990s onwards. It was characterised by the liberalisation and commodification of education as imposed from above by central government in certain countries. As Kaščák and Pupala (2014) point out, the systematic changes in education saw a shift towards privatisation, in place of the centralistic, collectivistic traditions of the former Communist regime's education system. The authors stress the fact that education reforms have been significantly influenced by 'perpetual neo-liberalisation', a 'feature of government education discourse' (Kaščák \& Pupala, 2014). This discourse focuses on simplistic interpretation of economic 'competitiveness' in education, which is perceived as a mere 'commodity' in a distorted market (public institutions financed by the State; private ones by students' fees, with access to additional state funding, including European funds). All HE institutions are defined as providers competing for 'customers' (students) and resources (funds/projects).

In the late 1990s, governmental reforms opened the education sector to private $\mathrm{HE}$ institutions in most CEE countries; these were obliged to obtain State authorisation, including the accreditation of their programmes by a State accreditation board. The over simplistic liberalisation and commodification of the educational sector increased the number of HE institutions, and accordingly the number of political science chairs. As Fig. 5.1 shows, there was a significant rise in the number of such institutions (which almost doubled) offering political science (PS) programs in the Czech Republic, Hungary, Romania and Slovakia. The mushrooming of 
No. of higher education institutions with political science program

90

80

70

60

50

40

30

20

10

0

program

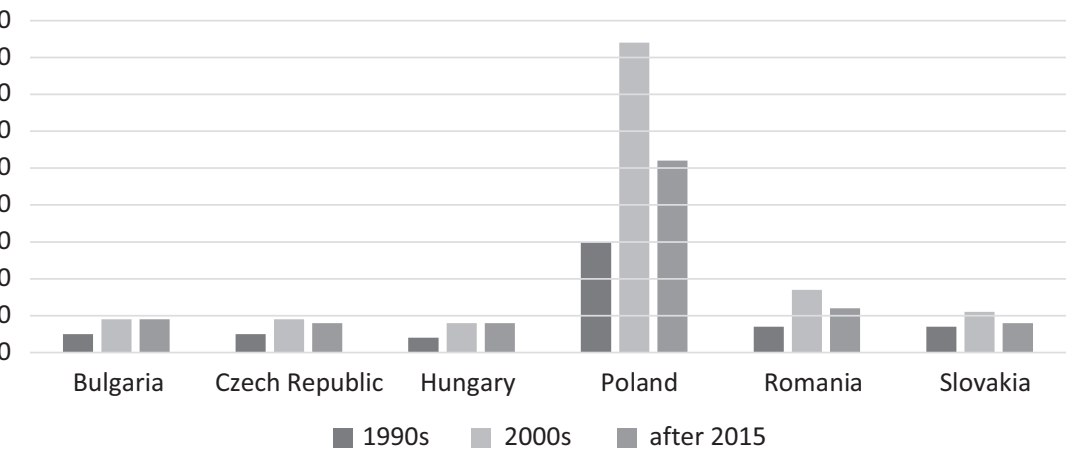

Fig. 5.1 Number of HE institutions with a political science programme. (Source: PROSEPS National Reports on the State of Political Science 2019a-f; KrauzMozer et al., 2015 \& GUS, 2019)

new public and private institutions offering political science programmes was most spectacular in Poland. While during the 1990s, thirty HE institutions provided PS programmes, of which 17 were non-public, in the academic year 2009/10 the number reached its peak, with 84 schools ( 56 private) providing courses in political science (Krauz-Mozer et al., 2015; Sasinska-Klas, 2010). According to the most recent figures, there are now $52 \mathrm{HE}$ institutions offering political science programmes in Poland (GUS, 2019).

At the same time, this was a period when governmental reforms changed the financing of higher education. The system of annual lump sum allocations per public HE institution was replaced by financing rules based on the number of students and/or teaching staff. As the allocation of State funding was almost exclusively based on student numbers, and failed to reflect research performance or the quality of teaching in a given $\mathrm{HE}$ institution, there was little incentive for institutions to build an outstanding academic reputation (also in regard to research work).

The launching of private universities and colleges, and the allocation of funding based on the number of students and/or staff in case of public HEIs had a significant impact on the institutionalisation of political science. Many private, and some of the public, HE institutions of course 
adopted profit-seeking strategies. The emphasis on the principle of 'quantity' in regard to the substantial increase in students and teachers, proved key during this period. In terms of the increase in numbers, this model was justified. In terms of the quality of teaching and research, it does not appear so.

We consider this period of institutionalisation as coercive in keeping with Di Maggio \& Powell's classification (1983). The main impetus to various $\mathrm{HE}$ institutions to adopt their strategies and implement changes came from the governmental reforms that introduced certain opportunities (e.g. concerning education) as well as constraints (e.g. concerning research). Additionally, the profit-seeking strategies adopted by some $\mathrm{HE}$ institutions (e.g. the introduction of part-time studies of political science, and increasing the number of PS students) were mimetically followed by others $\mathrm{HE}$ institutions competing at the same education market. Looking at quantitative indicators only, this period led to unprecedent massification and commodification in CEE, since at that moment the number of students and of HE institutions offering political science programmes, reached its peak.

The last phase-the regulatory phase-followed the change in the political discourse regarding education during the first decade of the 2000s. With the introduction of the Lisbon Strategy (2000) at EU level, discourse has focused on competitive education as a way of building a knowledge society and economy, and has transformed the perception of education's value. Over the last two decades or so, leading politicians' technocratic approach to education has dominated public and media discourse. In several CEE countries, politicians have systematically favoured those academic programmes of a technical and high-tech nature, over the social sciences and humanities, claiming that they better fit labour market demands. The last phase - the regulatory phase-began at various times, depending on the country, over the period 2010-2015 when the tightening of HE regulation was debated and attempted in the majority of CEE countries. The initiative for such regulation came mainly from industry, which wanted higher education to be regulated so as to favour the technical and natural sciences. The reason for the need to regulate the choice of study programmes and the number of graduates in different professions in particular, was seen as the labour shortage in the automotive industry, which had become a very important sector in the CEE due to the inflow of direct foreign investments. The shortage was a consequence of the decrease in the total number of students on the one hand, and increased 
demand for professionals and skilled workers in those fields related to automobile production, on the other. Since 2000, the automotive industry has played a key role in the economies of the V4 countries and Romania, and has been crucial for their development. At the same time, this sector has been one of the largest employers in the V4 countries, accounting for $2-3 \%$ of the entire labour market. Since 2010 , employment in the automotive sector in CEE has grown constantly, and at a faster rate than in the EU28 (Dębkowska et al., 2019). As this industry requires an increasingly sophisticated and educated workforce, there has been a significant push for educational programmes with a technical focus at secondary and tertiary levels, especially over the last decade. Using the above-mentioned facts, influential automotive lobbyists have used their leverage to push for changes in educational policies. Furthermore, as Fig. 5.2 shows, there has been a fall in the birth rate in CEE since 1970s, with the sharpest drop over the period 1996-2000, which corresponds to an age cohort entering university in the years 2014-2018.

Current development of $\mathrm{HE}$ in most CEE countries is changing the system of institutional and programme accreditation and financing. There is a tendency to change the emphasis from a consideration of student number, to other, more qualitative criteria (research and publication outputs) when it comes to the financing of HE institutions. In many cases, this shift has affected study programmes in the social sciences, including

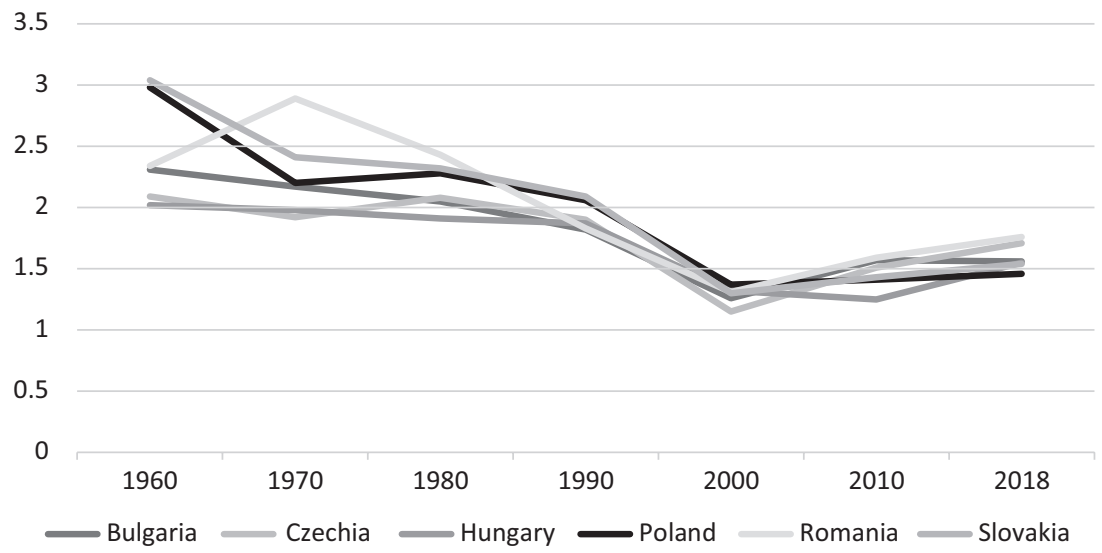

Fig. 5.2 Development of total fertility rate (1960-2018). (Source: Eurostat, 2020) 
political science. In most cases, the changes to the higher education funding system have allowed governments to prioritise study programmes and to (indirectly) influence the subjects taught. The allocation of State funding is based on three pillars: the evaluation of the curriculum, scientific activity, ${ }^{9}$ and the number of students who have found jobs pertaining to their studies. One very important factor influencing curriculum evaluation is the assessment of the subject field by the Ministry of Education, which decides whether a subject is to be considered a priority or otherwise. This procedure results in greater financial support for students of the prioritised fields. For example, in Slovakia and the Czech Republic, the governmental prioritisation of technical and natural sciences has resulted in a ministerial financial allowance methodology that increases funding for such study programs, as well as the entity of additional student allowances ${ }^{10}$ in these fields. In the case of Slovakia, in 2019 the political science coefficient for the financial allowance per student was 1.0 (the lowest one). The equivalent coefficient was 1.48 for IT engineering and 3.23 for architecture. ${ }^{11}$ In the Czech Republic in 2019, the coefficient for state budget distribution to HE institutions was set at 1.0 (the lowest one) for political science and international relations (and many other social sciences and humanities), compared to 2.8 for chemistry and materials science, and to 2.25 for mathematical engineering. ${ }^{12}$ Therefore, if a university has a study programme in mathematical engineering with 250 students, it impacts the entity of state subsidies, since the standard allowance per student is multiplied by a coefficient of 2.25 . When compared this to a study programme in political science with 250 students, in this case, the allowance per student remains at the basic level (based on a coefficient of 1 ). This encourages $\mathrm{HE}$ institutions to promote study programmes providing greater

\footnotetext{
${ }^{9}$ Budget allocation reflects two scientific outputs: publications and research projects. There are various coefficients based on the quality of publications which are included in the formula for calculating the allocation per given HE institution. The same applies to research projects. Decisions regarding such coefficients lie with the Ministry, and the coefficients are usually adjusted on an annual basis.

${ }^{10}$ Social and merit stipends, for example. However, in some cases, prioritised study programmes are also now eligible for motivational stipends.

${ }^{11}$ Methodology of allowance allocation from state budget to public HE schools in 2019, viewed on 20.2. 2019 at: https://www.minedu.sk/data/att/14159.pdf.

${ }^{12}$ Nově stanovené keoficienty ekonomické náročnosti [New coefficients of financial demands]. Available 10.12.2019 at: https://www.msmt.cz/vzdelavani/vysoke-skolstvi/ nove-stanovene-koeficienty-ekonomicke-narocnosti-1.
} 
financial resources for the institution's coffers. Further information on how research is prioritised can be found in the appendix to Chap. 1 .

The impact of the above-mentioned tendencies and regulations is reflected in the number of PS students and of $\mathrm{HE}$ institutions providing PS programs. We will examine student numbers in more detail in the next section. As far as regards the impact on HE institutions, Fig. 5.1 shows a downward trend. With the exception of Bulgaria, the number of HE institutions offering political science programmes in all other countries has fallen. However, the overall number of HE institutions is still higher than it was in the 1990s. Government incentives for the promotion of quality rather than quantity (the opposite was the case during the proliferation period) are not systematic, however. Furthermore, more serious risks are associated with governmental attempts to boost certain HE study programs at the expense of others.

The governments in the CEE region are imposing new rules on higher education which clearly test the stability of our discipline.

The institutional transformations in a given period are again twofold, as seen from the perspective of Di Maggio and Powell (1983). The normative aspect is present in the initiative from within to adopt qualitative measures and follow a modern (EU or Western) path of education and research. The coercive aspect is present vis-á-vis many $\mathrm{HE}$ institutions that have had to change their coping strategies. Since the beginning of this regulatory phase, $\mathrm{HE}$ reforms have been based on educational ranking and financial constraints and have had a serious impact on the social sciences and humanities. In a certain way, this period has challenged and tested the endurance of political science as a discipline.

\subsection{Students of Political Science: From an Explosion in Numbers to Their Recent Decline}

During the proliferation phase of the discipline's development in CEE (late 1990s-2000s), there was a significant increase in the number of students studying political science.

As Table 5.2 shows, the number of students enrolled in political science significantly increased at first, but then substantially declined thereafter, except in the Czech Republic: this exception is probably due to the appeal of Czech universities and cities to foreign students (from EU and non-EU countries alike). In some cases, the initial increase in numbers was incredible: as in the Czech Republic for example (where numbers almost 
Table 5.2 Number of students in political science programmes ${ }^{d}$

\begin{tabular}{lccc}
\hline Country & 2000 & 2009 & 2018 \\
\hline Bulgaria & 1490 & $4010^{\mathrm{a}}$ & 2507 \\
Czech Republic & 828 & 3567 & 3058 \\
Hungary & $2867^{\mathrm{b}}$ & 2870 & 1516 \\
Poland & 47,842 & 55,000 & 17,579 \\
Romania & 13,377 & 48,384 & $15,020^{\mathrm{c}}$ \\
Slovakia & 906 & 3049 & 597 \\
\hline
\end{tabular}

Source: The PROSEPS National Reports on the State of Political Science 2019a-f; Krauz-Mozer et al. (2015), GUS (2019); Hungarian Educational Database (2020)

aData only available for 2013

bData only available for 2006

'Data only available for 2017

dStudents specialising in politology, international relations, public policy and administration are considered as PS students

quadrupled), or in Poland where the number of political science students peaked at a record 55,674 in the academic year 2004/05, compared to the figure for 1993/4 which stood at a mere 8713 (Krauz-Mozer et al., 2015). In Slovakia and Romania, the number more than tripled, while in Bulgaria the number of PS students more than doubled.

The reasons for such an increase may be found in several structural factors, and also in certain personal factors. As already mentioned above, the liberalisation of the educational market had increased the number of $\mathrm{HE}$ institutions offering political science programmes. At the same time, the financial incentives resulting from by governmental funding of HE institutions based on enrolment numbers, led to the proliferation of enrolment in public HE institutions.

However, the profit-seeking strategies of $\mathrm{HE}$ institutions are only one side of the story, that is, the supply side. The other aspect, the demand side, concerns the perception of political science as an attractive academic subject area. The successful development of political science in CEE countries has contributed to the consolidation of democracy, thanks to the establishment of important research and teaching facilities that have actively participated in the analysis of contemporary problems, and in explaining and teaching people how democracy works. After the period of democratic consolidation, the increased relevance of political scientists' 
opinions, as expressed in the media, supported the relevance of political science as a whole. Students who chose political science as a future profession perceived it as something 'fancy' offering various career opportunities, and relatively easy to study even part-time. The other factor contributing to this proliferation concerns the transformation of the public administration in most post-communist countries. As state employees have to hold a university degree, the study of political science was often perceived as a means of self-improvement, or as a very easy degree option. Such factors, together with the significant numbers of young people, ${ }^{13}$ contributed to the boom in the number of political science students.

However, over the last decade (i.e. since 2010), the number of political science students, which is an indicator of the discipline's stability, has declined. As Table 5.2 indicates, the drop in numbers has been quite significant. For example, in the case of Poland, where PS students had remained at around 55,000 in the period 2004-2009, the numbers started to drop rapidly over the following decade and were down to 25,054 by the academic year 2011/2012 (Krauz-Mozer et al., 2015). Slovakia saw an even greater reduction in political science student numbers, which shrank to almost one-fifth of the previous figure. In other countries (with the exception of the Czech Republic), the drop was less dramatic, but still persists.

One possible explanation for such a decline in numbers could be the overall demographics of the region. The fertility rate fell from 1992 until around 2000, and increased only slightly thereafter (see Fig. 5.2). This decrease impacted the university student population in the period 2010-2018, and may have influenced enrolment in political science.

With fewer young people available for tertiary study enrolment, ${ }^{14}$ the fertility argument would seem a plausible one (see also EACEA, 2018, pp. 25-26; Santa, 2018; Krauz-Mozer et al., 2015). However, the loss of students is evident not only in real numbers, but also in the share that political science students represented of the total population of university students (see Table 5.3). The CEE countries examined here reveal a

\footnotetext{
${ }^{13}$ See Fig. 5.2: the rate of birth in the late 1980s-mid-1990s had a significant impact on the 18-19 age cohort at the beginning of the new millennium.

${ }^{14}$ Looking at the entire period from 2010 to 2015 , the total number of students enrolled in tertiary education was lower in 2014/15 than in 2009/10 in the countries examined here. The decrease was most pronounced in Romania (45.8\%), but in other countries like Slovakia, the Czech Republic, Poland and Hungary, the decrease was also significant, ranging between $20 \%$ and $30 \%$ (EACEA, 2018).
} 
Table 5.3 Share of political science students among university students

\begin{tabular}{|c|c|c|c|c|c|c|}
\hline \multirow[t]{2}{*}{ Country } & $\begin{array}{l}\text { Total UNI } \\
\text { students }\end{array}$ & $\begin{array}{l}\text { PS } \\
\text { students } \\
(\%)\end{array}$ & $\begin{array}{l}\text { Total UNI } \\
\text { students }\end{array}$ & $\begin{array}{l}\text { PS } \\
\text { students } \\
(\%)\end{array}$ & $\begin{array}{l}\text { Total UNI } \\
\text { students }\end{array}$ & $\begin{array}{l}\text { PS } \\
\text { students } \\
(\%)\end{array}$ \\
\hline & 2000 & 2000 & 2009 & 2009 & 2018 & 2018 \\
\hline Bulgaria & 243,592 & 0.61 & $277,239^{a}$ & $1.45^{\mathrm{a}}$ & 229,771 & 1.09 \\
\hline $\begin{array}{l}\text { Czech } \\
\text { Republic }\end{array}$ & 190,203 & 0.5 & 388,990 & 0.9 & 290,099 & 1.05 \\
\hline Hungary & 180,000 & 1.6 & 240,000 & 1.2 & 200,000 & 0.76 \\
\hline Poland & $1,570,000$ & 3.0 & $1,890,000$ & 1.3 & $1,291,870$ & 1.3 \\
\hline Romania & 533,152 & 2.5 & 891,000 & 5.4 & $408,179^{\mathrm{b}}$ & $3.7^{b}$ \\
\hline Slovakia & 136,922 & 0.7 & 225,588 & 1.4 & 136,684 & 0.4 \\
\hline
\end{tabular}

Source: Authors calculations based on data from the PROSEPS National Reports on the State of Political Science 2019a-f; GUS (2019) and Hungarian Educational Database (2020)

${ }^{\text {aD }}$ ata available for 2013

bData available for 2017

smaller share of students choosing to study political science in $2018 \mathrm{com}$ pared to 2009. The exception of the Czech Republic might be partly accounted for by Czech universities long-term strategy of attracting foreign students from other CEE countries. Thus, the Czech HE institutions apparently have capitalised on the language and cultural proximity to Slovakia, and the number of PS students has remained stable. The question is: why is political science not as attractive as it used to be a decade ago, in most cases?

Alongside the fall in the number of students for demographic reasons and due to a significant number studying abroad, another important factor accounting for such decline is that of the greater regulation of tertiary education to bring it into line with labour-market demand. Educational managers, policy makers, and politicians who want to achieve returns on public moneys, have disputed the relevance of various professions, including that of political scientists. Spreading distrust towards the discipline may well have lessened the appeal of political science, while fluctuations in student numbers represents a potential threat to further stability and legitimacy, that is, to the overall institutionalisation of political science. 
In the next section, we shall provide a few examples demonstrating that similar patterns prevail. This has been demonstrated by the expert assessments (PROSEPS project) surveys as well.

\section{Political Science: A Discipline Under Pressure?}

In CEE there are indications of persisting tendencies towards the erosion of political science's legitimacy as an educational program and discipline over the last decade (since 2010). Such tendencies are not generalised or identical in all of the countries examined in this chapter, but they are present to a greater or lesser extent in most of them. We identified three main strategies of discursive deterioration: (1) the prioritisation of labour market demands; (2) the prioritisation of technical disciplines; and (3) a disregard for political science (as a science) for political reasons. In some countries, as we shall show below, such discursive downgrading preceded significant political decisions that have worsened the recognition, status and/or financing of political science.

The increase in the unemployment rate among younger people shortly after the 2008-2009 financial crisis, led to a debate on 'useful' versus 'useless' fields of study in the Czech Republic, for instance. One of that country's right-wing populist MPs (Úsvit-Národni koalice) gave the following opinion of the humanities: 'Certainly we do not need so many historians, sociologists, political scientists...I think there are many people of such profession and have troubles to find a job... What we need are the fields that have added value and bring finances to economy. These are disciplines that produce something, they bring added value' (Hajdučková, 2017).

A crucial tendency to favour technical subjects over others, and to denigrate the social sciences, especially political science, was also evident in the Slovak Republic. The Minister of Labour and Social Affairs (SMER-SD), during his annual briefing on the issue of unemployment, repeatedly presented political science, along with pedagogy, psychology and economy, as the educational fields characterised by the highest rates of unemployed graduates (Pravda, 2019; SME, 2015). The portrayal of political science as of little use is something that the prime minister for nine years, Róbert Fico (SMER-SD), did systematically in the media According to Fico, the Slovak education system produces an 'enormous amount of political scientists, lawyers and social workers who are unemployable in the job market' (TASR, 2014). In his address to high school students he said: 'you can study useless political science, you can study useless international relations, 
you can study whatever is so popular today, but I guarantee you, you won't be able to find a job' (Denník, 2017). Moreover, he considers it 'a mistake if somebody is eager to study political science or international relations. We have thousands of such people. Who would need an organiser of spare time with a university diploma?!' (Pravda, 2018) Populist politicians backed by an industrial lobby stress the idea that Slovakia is the most industrial country in the EU, which is why it needs technically skilled people. Technical education at secondary and tertiary levels has been a key priority for recent governments, and this has been extensively divulged to the public via the media (e.g. Hospodárske noviny, 2015; Pravda, 2018; RTVS, 2017; SME, 2016; TA3, 2014; TA3, 2017; TASR, 2014).

In some cases, the importance of technical skills has been translated into policy actions. The National Employment Strategy of the Slovak Republic to 2020 (Ministry of Labour, Social Affairs and Family of the Slovak Republic, 2014) offered specific support for the technical and natural sciences within the Slovakian education system. As we stated above, this has led to a new ministerial approach resulting in increased subsidies for such technical and technological disciplines, together with a special motivation stipend provided to students enrolled in these programmes. In 2019, the Czech Ministry of Education, Youth and Sports introduced a pilot project integrating technical education into the curriculum of the country's elementary schools. ${ }^{15}$ The aim of the project is to combine both the traditional approach to learning manual skills and the use of modern technologies (applied IT). The term 'support to engineering thinking' is also used in this context. ${ }^{16}$

In the case of Bulgaria, until 2016 the approach to higher education had been a liberal one; however, the Ministry of Education declared this a failure as the country's open borders led to a brain-drain on the one hand, and students unable to find jobs commensurate with their studies and training on the other. According to the government, only $10 \%$ of students choose academic discipline that is seen as valuable for economic growth of the country. The Minister of Education (a member of the conservative, populist GERB party), stated that the country has 'no need for new centres for the teaching of political science or law. We have a need for

\footnotetext{
${ }^{15}$ Schools for children in age of $6-14$ years.

${ }^{16}$ https://www.msmt.cz/novinky-ve-skolnim-roce-2019-2020?highlightWords=pilotn\% C3\%AD+ov\%C4\%9B\%C5\%99ov\%C3\%Aln\%C3\%AD+technika.
} 
engineering and technical education centres' ${ }^{17}$ These types of arguments are fairly common in Hungary as well. Together with Hungarian politicians' public denigration of political science as a discipline worth studying, the professionalism of the discipline, in the eyes of the public, is also being questioned elsewhere (Koper, 2017). An academic analysis of the profession stated that in in case of the Czech Republic, 'hardly anybody in the general public perceives political science as a science worthy of the name' (Holzer \& Pšeja, 2010, p. 113). Even if this conclusion might sound somewhat exaggerated, we found sound, valid reasons why the public's perception of political science has been portrayed in a negative light in the majority of the countries under scrutiny. Firstly, the above authors pointed to the popular perception of political scientists as people offering analysis and observations designed to fit specific political requirements. Secondly, they observed that political scientists generally acknowledged as leaders in the field of research, hardly ever participate in public debates or appear in the mass media (Holzer \& Pšeja, 2010). The combined impact of such perceptions can lead to political science's role being downgraded to that of a pseudoscience providing only opinions and observations. One of the most recent examples of this attitude towards political science is a social network post by a Slovak MP (candidate of ĽSNS): ' ...the biggest pseudoscience in human history: political science. People who finish [such study] usually don't know anything, they act as windbags who pretend to know world better than others ${ }^{18}$ He responded to criticism from a political scientist who had labelled his political party as one of moderate fascists or religious extremists, and potentially linked with tendencies toward democratic backsliding in Slovakia. The depiction of political science as a pseudoscience is quite common in online debates. The roots of such discursive strategies go back to the communist period. Political science was officially banned as a 'bourgeois pseudo-science' shortly after the communists gained power in the CEE region (Ágh, 1991; Malová \& Miháliková, 2002). The current instrumental use of this kind of portrayal of political science by politicians, especially when they are faced with critical analysis, serves the purposes of de-legitimisation.

Another example of the tendency to de-legitimise political science as a discipline and field of research is the recent battle against 'gender

\footnotetext{
${ }^{17}$ Interview with the Minister of Education and Science, 14 June 2019.

${ }^{18}$ Available online at: https://www.facebook.com/107752747505118/posts/1440024 $57213480 /$ [posted on 28 May 2020; accessed 30 July 2020].
} 
ideology' in the CEE region. Conservative populist politicians perceive gender studies as part of a 'gender ideology', that is a systematic attempt to erode conservative values and traditional ways of living in the CEE region. Needless to say, 'gender studies' is a scientific term that is accepted by all those studying the relations between men and women.

Hungarian Prime Minister Victor Orbán declared the battle against liberal democracy and liberal values, including 'gender craziness' (gender"orület), to be 'a mission of our generation' for the next 15 years. ${ }^{19}$ In this battle, his administration has progressively taken control over public media and academia by systematically weakening their autonomy. The Hungarian Academy of Sciences has been deprived of its research institutes, including its Social Science Research Centre which comprises political science research. The new organisational framework is under strict government control, and applied research is expected to be the new direction it will be going in. Governmental (party) functionaries have descended on public universities, controlling them tightly. Private higher education institutions have partly escaped such control, though not entirely. The public's attention has probably focused in the main on the government's attempt to evict the privately funded Central European University (CEU) from Hungary, which was broadly discussed even beyond Hungary's borders. The CEU declares itself to be an institution 'committed to promoting the values of open society and self-reflective critical thinking', ${ }^{20}$ which is not in line with the 'illiberal democracy' as the regime defines itself. In 2017, Parliament passed a law setting out conditions that threatened to render the CEU's continued presence in the country illegal. The government denied the CEU's accreditation for the purposes of granting US degrees in Hungary, which led to it eventually moving to Vienna. In addition to the attack on the CEU, a campaign was waged against the new Gender Program at the Social Sciences Faculty of Eötvös Lóránd University via government-friendly media. As a form of response, the government decided to set up a program of Family Studies at Corvinus University Budapest. As has happened in other CEE countries, conservative forces have labelled 'gender studies' as a gender ideology harming the traditional values of Hungarian society by promoting anti-family values. The rival

\footnotetext{
${ }^{19}$ Prime Minister Viktor Orbán's speech at the 30 Bálványos Summer Open University and Student Camp, 27 July 2019, Tusnádfürdő.

${ }^{20}$ https://www.ceu.edu/about/our-mission.
} 
programme of 'family studies' is expected to be much more in keeping with the present government's ideology.

In this regard, political discourse and/or national policies do harm academic freedom, and force political scientists to work under pressure. In some cases, the government can even put undue pressure on international research projects. An example of this is the Bulgarian project 'Forum for gender-balanced model at school: the Bulgarian case', which was included in the first phase of UNESCO's Programme 2018-2019. The goals of the project were misrepresented, with its critics accusing it of peddling 'gender ideology' and 'brainwashing students'. The actual goal of the project was to analyse teacher competence and motivation in order to uphold, and teach students, the principles of gender equality in accordance with the spirit of UNESCO's Gender Equality Action Plan (2014-2021) and its Major Programme 2 'Education'. These goals were in accordance with Bulgaria's National Strategy for 'Encouraging Equality between Men and Women' (2016-2020) and the 'Law on Equality between Women and Men' as published in the State Gazette (Issue 33, 26.04.2016).

Instead of supporting these policies, the Bulgarian Ministry of Education and Sciences, in a slanderous media campaign, demanded the proposal be terminated. Obviously, as on other occasions, the term 'gender' is the scarecrow term designed to mobilise popular support. Over the course of several months, the term was presented to Bulgarian society in a manipulative way. The Ministry, instead of going something about the attack on political scientists, asked them to give up the proposed project. This raises the question as to whether, from now on, anyone who dares to do research on gender themes such as equality, discrimination, violence, inequality, and so on will be ostracised. At a time when we speak of 'Science and education for smart growth', the project has been presented as a mortal threat to Bulgaria's schools, with 'gender agents' endangering the lives of Bulgarian students.

In our view, this is a very serious case of censorship in which academic freedom is suppressed. The academic community has to have the freedom to select research fields in compliance with academic standards and ethical norms. By adopting various different approaches, political scientists contribute towards the critical assessment of political alternatives. The attack on this project has provided a new opportunity to argue that scientists should participate actively in policy debates, both as professionals possessing relevant knowledge and as educated citizens, rather than being simply burdened with academic work. 


\section{Conclusion}

By comparing these six CEE countries, one important finding that has emerged is that there are substantial fundamental similarities and similar developmental trends, in political science across the six countries in question. Moreover, the same concerns prevail in regard to the state and development of political science within this group of countries. In this chapter, we have examined the current state of the discipline, and in particular the two key proprieties of institutionalisation: stability and legitimacy. We have looked at specific cases in order to establish the ways in which governments interfere in public discourse, and set up institutional arrangements impacting the institutionalisation of political science as a discipline. Our analysis spanning three decades suggests that political science as a discipline has been stable over time, in terms of its endurance and/or constancy. However, our findings also indicate that its resilience over time is still rather weak, that is: its capacity to face and adapt to external challenges (imposed by governments) and changing structural factors has proven rather weak, as its legitimacy has been increasingly tested by political elites and lobbies of industrialists.

The (re)launch of political science as an academic and scientific discipline after the collapse of Communism in 1989 was followed by the quest for an institutional framework comprising chairs in political science, academic journals and professional organisations. In most cases, the initial phase of this institutionalisation process was completed by 1995. In the late 1990s, the governmental push for the liberalisation of the educational sector had resulted in an increase in the number of HE institutions, and accordingly in the number of political science chairs. We have referred to this phase of institutionalisation as the 'proliferation phase', consisting in the establishment of private HE institutions and the allocation of educational funds based on the number of students and/or staff. This phase led to the adoption of profit-seeking strategies by many HE institutions. The model of public funding favoured education over research, and led to an increase in PS student numbers. The appeal of political science as a relatively new discipline was also a contributing factor.

After 2010, discussions were held and attempts made regarding the adoption of further regulations. These efforts were a consequence of the fall in the total number of students due to demographic change and a significant exodus of students to foreign countries. As a consequence, attracting more students required considerable effort, and more often 
than not the strategy adopted was either that of improving the educational offer, or offering a very easy path to the desired diploma or degree. Regulations were introduced as a necessary step towards improving the quality of higher education in the region. Favouring quality (with the emphasis on research) over quantity (to the latter having been targeted during the proliferation period) is not such a bad thing. However, there are greater risks associated with the governmental attempts to boost certain HE programs at the expense of others that have accompanied the changes in the rules. Politicians' discursive strategies aimed at promoting specific academic disciplines, has been an additional factor in the reduction in PS student numbers.

The education debate in the countries concerns has focused on competitiveness bolstering education with a natural science and technical focus. This approach could significantly affect the social sciences, and political science in particular, by reducing their role in, and appeal to, society (by contributing to their de-legitimisation). In our opinion, to date political science has managed to remain stable in terms of dynamic continuity (persistence and development) but has not seen any significant growth. However, the intervention of governing institutions in the policies adopted by educational institutions could have negative effects on political science, as falling student numbers could lead to the discipline being less involved in scientific research, international cooperation and innovation.

\section{REFERENCES}

Ágh, A. (1991). The Emergence of the "Science of Democracy" and Its Impact on the Democratic Transition in Hungary. Aula, 13(2), 96-111.

Arató, K., \& Tóth, C. (2010). Political Science in Hungary: A Discipline in the Making. In R. Eisfeld \& L. A. Pal (Eds.), Political Science in Central-East Europe. Diversity and Convergence (pp. 149-163). Barbara Buldrich Publishers. Barbu, D. (2002). Political Science - Romania. In M. Kaase, V. Sparschuh, \& A. Wenninger (Eds.), Three Social Science Disciplines in Central and Eastern Europe: Handbook on Economics, Political Science and Sociology (1989-2001) (pp. 322-342). Informationszentrum Sozialwissenschaften.

Dębkowska, K., et al. (2019). The Automotive Industry in the Visegrad Group Countries. Polish Economic Institute.

Di Maggio, P. J., \& Powell, W. W. (1983). The Iron Cage Revisited: Institutional Isomorphism and Collective Rationality in Organizational Fields. American Sociological Review, 48(2), 147-160. 
EACEA. (2018). The European Higher Education Area in 2018: Bologna Process Implementation Report. Publications Office of the European Union.

Eisfeld, R. \& Pal, L. A. (2010). Political Science in Central-East Europe and the Impact of Politics: Factors of Diversity - Forces of Convergence. In R. Eisfeld \& L. A. Pal (ds.), Political Science in Central - East Europe. Diversity and Convergence (pp. 9-37). : Barbara Budrich Publishers.

Eurostat. (2020). Fertility Statistics. Retrieved May 2, 2020, from https://ec. europa.eu/eurostat/statistics-explained/index.php/Fertility_statistics

Gebethner, S., \& Markowski, R. (2002). Political Science - Poland. In M. Kaase, V. Sparschuh, \& A. Wenninger (Eds.), Three Social Science Disciplines in Central and Eastern Europe: Handbook on Economics, Political Science and Sociology (1989-2001) (pp. 306-321). Informationszentrum Sozialwissenschaften.

Ghica, L. A. (2014). Academic Bovarism and the Pursuit of Legitimacy: CanonBuilding in Romanian Political Science. European Political Science, 13, 171-186.

GUS. (2019). Szkolnictwo wyższe w roku akademickim 2018/2019. [Higher Education in Academic Year 2018/2019]. Retrieved June 13, 2020, from https://stat.gov.pl/obszary-tematyczne/edukacja/edukacja/szkolnictwowyzsze-w-roku-akademickim-20182019-wyniki-wstepne, 8,6.html

Hajdučková, M. (2017). Poslanec Fiedler: Za volbu humanitního zaměření mohou maminky a výchovné poradkyně. [MP Fiedler: Moms and Educational Councelors Are Responsible for Choice to Study Humanities]. Retrieved April 11, 2020, from https://www.el5.cz/the-student-times/poslanecfiedler-za-volbu-humanitniho-zamereni-mohou-maminky-a-vychovneporadkyne-1331384

Hankiss, E. (2002). Brilliant Ideas or Brilliant Errors? Twelve Years of Social Science Research in Eastern Europe. In M. Kaase, V. Sparschuh \& A. Wenninger (Eds.), Three social science disciplines in Central and Eastern Europe: handbook on economics, political science and sociology (1989-2001) (pp. 17-24). Berlin: Informationszentrum Sozialwissenschaften.

Hansson, S. O., \& Helgesson, G. (2003). What Is Stability? Synthese, $136(2), 219-235$.

Holzer, J., \& Pšeja, P. (2010). Political Science in the Czech Republic: On the Edge of Maturity. In R. Eisfeld \& L. A. Pal (Eds.), Political Science in CentralEast Europe. Diversity and Convergence (pp. 103-119). Barbara Budrich Publishers.

Hungarian Educational Admissions Database. (2001-2020). Retrieved June 3, 2020, from https://www.felvi.hu/felveteli/ponthatarok_statisztikak

Huntington, S. P. (1988). One Soul at a Time: Political Science and Political Reform. The American Political Science Review, 82(1), 3-10.

Kaase, M., Sparschuh, V., \& Wenninger, A. (Eds.). (2002). Three social science disciplines in Central and Eastern Europe: handbook on economics, political 
science and sociology (1989-2001). Berlin: Informationszentrum Sozialwissenschaften.

Kaščák, O., \& Pupala, B. (2014). Towards Perpetual Neoliberalism in Education: The Slovak Path to Postcommunist Transformation. Human Affairs, $24,545-563$.

Koper, J. (2017). Apologia pro Politica Scientia [Defense of Political Science]. Politické vedy/Political Sciences, 20(1), 11-33.

Kostova, D., \& Avramov, K. (2010). Political Science in Bulgaria: The Legacy of Discontinuity. In R. Eisfeld \& L. A. Pal (Eds.), Political Science in Central East Europe. Diversity and Convergence (pp. 75-89). Barbara Budrich Publishers.

Krauz-Mozer, B., Borowiec, P., \& Ścigaj, P. (2015). The Condition and Perspectives of Polish Political Science in the Beginning of the 21 st Century. In B. Krauz-Mozer, M. Kułakowska, P. Borowiec, \& P. Ścigaj (Eds.), Political Science in Europe at the Beginning of the 21st Century (pp. 357-382). Jagiellonian University Press.

Malová, D., \& Miháliková, S. (2002). Political Science in Slovakia. In H. D. Klingemann et al. (Eds.), The State of Political Science in Central and Eastern Europe (pp. 253-274). Sigma.

Ministry of Labour, Social Affairs and Family of the Slovak Republic. (2014). Národná stratégia zemastnanosti Slovenskej republiky do roku 2020 [National Employment Strategy of the Slovak Republic to 2020]. Retrieved June 2, 2020, from https://www.employment.gov.sk/sk/praca-zamestnanost/ podpora-zamestnanosti/narodna-strategia-zamestnanosti/

Mingiu-Pippidi, A. (2010). Political Science in Romania: A Discipline from Scratch. In R. Eisfeld \& L. A. Pal (Eds.), Political Science in Central - East Europe. Diversity and Convergence (pp. 221-231). Opladen \& Farmington Hills, MI: Barbara Budrich Publishers.

Rybář, M. (2010). Political Science in Slovakia: Hesitant Emergence from Elementary Problems. In R. Eisfeld \& L. A. Pal (Eds.), Political Science in Central - East Europe. Diversity and Convergence (pp. 267-281). Barbara Budrich Publishers.

Santa, R. (2018). The Future of European Higher Education in an Age of Demographic Headwinds. In A. Curaj, L. Deca, \& R. Pricopie (Eds.), European Higher Education Area: The Impact of Past and Future Policies (pp. 369-386). Springer.

Sasinska-Klas, T. (2010). Political Science in Poland: Roots, Stagnation and Renaissance. In R. Eisfeld \& L. A. Pal (Eds.), Political Science in Central-East Europe. Diversity and Convergence (pp. 207-221). Barbara Budrich Publishers. Szabó, M. (2002). Political Science - Hungary. In M. Kaase, V. Sparschuh, \& A. Wenninger (Eds.), Three Social Science Disciplines in Central and Eastern Europe: Handbook on Economics, Political Science and Sociology (1989-2001) (pp. 258-274). Informationszentrum Sozialwissenschaften. 


\section{Primary Sources}

Denník, N. (2017). Kažimír a Fico vidia problém v školstve, nová koncepcia v nesystémových krokoch a nedostatku financií [Kažimír and Fico See Problem in Education, the New Strategy Points on Non-systematic Approach and the Lack of Finance], 28.03.2017.

Hospodárske noviny. (2015). Minister Richter: Slovensko sa nachádza na šesťročných minimách nezamestnanosti [Minister Richter: Slovakia is at 6-years' minimum in unemployment], 19.10.2015.

Pravda. (2018). Je chyba, ak sa niekto trepe na politológiu, tvrdí Fico. Vyzýva na podporu remeselníkov [It is a mistake when somebody is struggling to study political science, says Fico. He appeals to support craftsmen], 18.02.2018.

Pravda. (2019). Richter: Vysokoškoláci sú ochotnejší prijať nižší plat ako stredoškoláci [Richter: University graduates are willing to accept lower salary than high school absolvents], 21.03.2019.

PROSEPS. (2019a). National Report on the State of Political Science, Bulgaria.

PROSEPS. (2019b). National Report on the State of Political Science, Czech Republic.

PROSEPS. (2019c). National Report on the State of Political Science, Hungary. PROSEPS. (2019d). National Report on the State of Political Science, Poland.

PROSEPS. (2019e). National Report on the State of Political Science, Romania.

PROSEPS. (2019f). National Report on the State of Political Science, Slovakia.

RTVS. (2017). Slovensko rokuje so stovkou investorov [Slovakia Is Negotiating with a Hundred of Investors], 09.04.2017.

SME. (2015). Tak málo nezamestnaných sme už dávno nemali, vraví Richter [We Haven't Had So Low Unemployment in a Long Time, Says Richter], 19. 10. 2015.

SME. (2016). Vláda podporí Ukrajincov [The Government Will Support Ukrainians], 03.03.2016.

TA3. (2014). Nová stratégia zamestnanosti sa zameriava na zosúladenie vzdelávania a praxe [New Strategy Concentrates on Discrepancy Between Education and Market Demands], 25.11.2014.

TA3. (2017). Automobilkám chýbajú ludia [Automobile Industry Is Missing People], 27.02.2017.

TASR. (2014). Fico: Jedným z najväčších problémov je nesúlad vzdelávania s potrebami praxe [Fico: One of the Most Serious Problem Is Discrepancy Between Education and Market Demands], 25.11.2014. 
Open Access This chapter is licensed under the terms of the Creative Commons Attribution 4.0 International License (http://creativecommons.org/licenses/ by $/ 4.0 /$ ), which permits use, sharing, adaptation, distribution and reproduction in any medium or format, as long as you give appropriate credit to the original author(s) and the source, provide a link to the Creative Commons licence and indicate if changes were made.

The images or other third party material in this chapter are included in the chapter's Creative Commons licence, unless indicated otherwise in a credit line to the material. If material is not included in the chapter's Creative Commons licence and your intended use is not permitted by statutory regulation or exceeds the permitted use, you will need to obtain permission directly from the copyright holder. 